\title{
Do Analysts Underestimate Future Benefits of R\&D?
}

\author{
Mustafa Ciftci \\ Correspondence: Mustafa Ciftci, School of Management, Binghamton University, SUNY, PO Box 6000, \\ Binghamton, NY 13902-6000, United States of America. Tel: 1-607-777-4214. E-mail: \\ mciftci@binghamton.edu
}

Received: April 27, 2012

Accepted: June 18, 2012 Online Published: July 31, 2012

doi:10.5539/ibr.v5n9p26

URL: http://dx.doi.org/10.5539/ibr.v5n9p26

\begin{abstract}
This paper investigates whether future excess returns to R\&D-intensive firms documented in prior literature is due to mispricing or compensation for additional risk. Prior research provides evidence consistent with the explanation that the positive association is compensation for additional risk associated with R\&D (Chambers et al. 2002). I investigate another possibility: The future excess returns to R\&D are correction for undervaluation in the prior periods. I first investigate financial analysts' behavior about future benefits of R\&D-intensive firms because financial analysts are one of the most important information intermediaries between investors and managers. Moreover, investor dependence on analyst information is greater in R\&D-intensive firms (Barth et al., 2001). I find that analysts underestimate earnings long term growth in R\&D-intensive firms and correct their underestimation in following years. I also find that investors are not aware of analysts' underestimation of future benefits of $R \& D$ suggesting that investors are mislead by analysts long term forecasts.
\end{abstract}

Keywords: mispricing of R\&D, underestimation of future benefits of R\&D, analysts’ forecast revision

\section{Introduction}

Prior research has documented that Research and development (R\&D) expenditures are related to future excess returns (Chan, Lakhonishok, \& Sougiannis, 2001; Lev \& Sougiannis, 1996, Chambers et al., 2002). While some studies argue that these excess returns are due to greater risk associated with R\&D (Chambers et al., 2002; Ho et al., 2004), other studies argue that these excess returns are due to mispricing of R\&D (Lev and Sougainnis, Chan et al., 2001). In this paper I investigate whether future excess returns to R\&D is a compensation for risk or correction of undervaluation in prior periods. I focus on the relationship between R\&D intensity and analyst forecast because analysts are the most important information processors for investors. Hence their mis-estimation of future benefits of R\&D might mislead investors and lead to mispricing of R\&D. Since it takes up to eight years to realize the future benefits associated with $R \& D$ expenditures, I use long term growth estimates instead of earnings forecasts. If analysts underestimate the long term growth in earnings in R\&D-intensive firms, they will have to revise their long term growth estimates upwards in the following years as they correct their underestimation in the following years. This will result in positive association with R\&D intensity and revision in consensus (mean) analysts' forecast. Consistent with this prediction, I find that revision in consensus analysts' long term growth estimate is positively related to both measures of R\&D intensity: R\&D expenditures to market value of equity and R\&D capital to market value of equity. I also find that revision in consensus analysts' forecasts continues up to five-year after the initial estimate. This finding suggests that the future excess returns to R\&D-intensive firms may be due to analysts' underestimating the future earnings growth for R\&D-intensive firms.

Next, I investigate whether investors are misled by the errors in analysts' long term forecasts. Following Dechow and Sloan (1996), I use Miskin (1983) test to investigate the relationship between mispricing of R\&D and bias in analysts' forecasts with respect to R\&D. I first estimate the relation between R\&D and revision in analysts' long term growth estimates (prediction equation). The regression coefficient on the R\&D measure in this model reflects to what extent analysts underestimate the future benefits of R\&D. I find that this coefficient is positive. Next, using a returns model, I estimate the relation between R\&D and analysts long term forecast errors implicit in market prices. Coefficients from returns model provide an estimate of the market's perception of association between $R \& D$ and revision in analysts' long term forecasts. If investors are aware that analysts underestimate future benefits of R\&D, this coefficient should have the same magnitude and sign in both prediction and return equations. However, I find that the regression coefficient on $R \& D$ in prediction equation is significantly greater 
than the corresponding coefficient on the R\&D variable implied from the returns model (i.e. the coefficient of $R \& D$ in prediction equation is positive while the coefficient in returns model is negative). These results suggest that investors assume that analysts overestimate future benefits of R\&D while they actually underestimate them indicating that investors do not correct the bias in analysts long term growth estimates with respect to R\&D. This result suggests that mispricing of R\&D might be due to analysts' biased forecast of future benefits of R\&D.

This study contributes to discussion over future excess returns to R\&D-intensive firms. Even though several prior studies make conjectures that future excess returns to $R \& D$ is due to mispricing, there is no direct evidence in support of mispricing explanation. Chambers et al. (2002) and Ho, Xu, and Yap (2004) show that future excess returns to R\&D might be due to greater risk associated with R\&D intensive firms. Combining my results with their findings suggests that future excess returns to $R \& D$ are partly due to risk and partly due to mispricing of R\&D-intensive firms. In an efficient market all publicly available information should be incorporated into stock price and thus, all the securities should be correctly priced. Hence, one should not be able to generate excess returns holding certain stocks. However, prior research has indicated that stock prices are inefficient in incorporating public information into stock price. For example, Sloan (1996) shows that portfolios formed based on accruals generates future excess returns. Similarly, Lakhonishok et al. (1994) argue that future excess returns value portfolios is due to mispricing.I add to the line of research about market inefficiency with respect to future benefits of R\&D. The rest of this study is organized as follows. Section 2 provides literature review and research questions. Section 3 presents research design and section 4 presents sample characteristics. Section 5 presents future excess returns to R\&D-intensive firms. Section 4 provides evidence about association between R\&D intensity and revision in long term growth estimates. Section 5 documents the relationship between revision in analysts' forecasts and future excess returns and section 6 concludes.

\section{Literature Review and Research Questions}

R\&D expenditures have been a salient issue among practitioners and academia in recent years. Interest stems from growth in science and knowledge base and increase in R\&D intensity in the economy. Chan, Lakonishok and Sougiannis (2001) (CLS hereafter) show that estimated R\&D capital increased from 10\% in 1975 to $29 \%$ in 1995. Moreover, they state that the technology sector and the pharmaceuticals industry account for 40 percent of the S\&P 500 index and that the amount of R\&D spending in some major industries is larger than their earnings. In a similar vein, Federal Reserve economist Nakamura states that "US companies spend annually on intangibles is on par with the total corporate investment in physical assets” (Lev, 2004).

Consistent with growing importance of $R \& D$ expenditures in the economy, an area of interest by researchers in accounting and finance has been the valuation of R\&D expenditures (Pandit et al., 2011; Aboody \& Lev, 1998; Ali et al., 2012; Ciftci \& Cready, 2011; Ciftci et al., 2011; Lev \& Sougiannis, 1996; Sougiannis, 1994; Monohan, 2005; Matolsky \& Wyatt, 2008; Eberhart et al., 2004 and 2008, etc.). Ciftci et al. (2011) and Lev and Sougiannis (1996) show that there is a positive association between ratio of $R \& D$ to market value of equity and future excess returns even after controlling for common risk factors such as size and book to market. CLS document a similar relationship by using a different measure of R\&D intensity: The ratio of R\&D expenditures to market value of equity. Some studies argue that future excess returns to $R \& D$ expenditures are compensation for additional risk associated with R\&D investment. Chambers et al. (2002) argue that conventional controls for risk like book-to-market and size do not control for R\&D risk factors causing measured excess returns to be biased upward. Ho, Xu, and Yap (2004) show that (1) R\&D intensity is positively related to systematic risk; (2) the greater systematic risk is attributable to greater intrinsic business risk and greater operating risk. Kothari et al. (2002) show that variability of future earnings for $R \& D$ expenditures is much greater than that for capital expenditures and concludes that future benefits associated with $R \& D$ is far more uncertain than that of capital expenditures. Ciftci and Cready (2011) show that CAPM beta increases with R\&D intensity.

An alternative explanation for future excess returns to $R \& D$ expenditures is mispricing. If investors undervalue R\&D-intensive firms, they will have to correct their undervaluation in following periods. This would result in future excess returns to R\&D-intensive firms. Even though it has been shown that R\&D expenditures generate future earnings up to eight year after the investment date, GAAP does not treat R\&D expenditures like other assets. SFAC No.2 requires that R\&D expenditures be expensed as they incurred even though they generate future earnings. As a result of expensing convention, reported earnings may materially differ from economic earnings based on capitalization of R\&D expenditures (Lev \& Zarowin, 1999). Moreover, since R\&D assets are not capitalized, the reported assets for R\&D-intensive firms are understated. Consequently, the distortion in financial information in R\&D intensive firms might lead to misstatement of conventional benchmark such as earning-to-price, book-to-market, return on equity. More specifically R\&D-intensive firms may appear to be "expensive" by such criteria (CLS). 
Therefore, investors in R\&D-intensive firms have to adjust financial numbers to eliminate the impact of expensing convention. If investors accept financial statements at face value, this raises the possibility that investors underestimate the future benefits associated with R\&D expenditures and undervalue these expenditures. Thus, future excess returns to R\&D may be correction of undervaluation in prior periods.

In this paper I investigate whether future excess returns to R\&D is due to mispricing or risk. To explore this question I first investigate the relationship between R\&D intensity and analysts long term growth estimates. Prior research suggests that financial analysts are information processors of investors (Barron, Byard \& Kim, 2002). Moreover, investor dependence on analysts' information in valuation of securities is greater in R\&D-intensive firms. (Barth et al., 2001) Investors use analysts' forecasts to form their expectations about future benefits of firms. Prior studies indicate that when analysts underestimate (overestimate) of future growth in earnings, this may result in undervaluation (overvaluation) of securities. For example La Porta (1996) show that value-glamour anomaly documented by Lakonishok, Shleifer and Vishny (1994) is due to investors accepting analyst long term growth estimate at its face value even though these forecasts are overly optimistic. Consequently, analysts' forecasts might play a role on mispricing of analyst as well. If R\&D-intensive firms are mispriced, it might be due to analysts' underestimating future benefits of R\&D expenditures and investors using analysts biased forecasts. Alternatively, analysts might be correctly estimating future benefits associated with R\&D expenditures but investors do not use this information. To investigate these two possibilities I investigate the relationship between $R \& D$ intensity and revision in consensus analysts' long term growth estimates. Since it takes up to eight years to realize the future benefits associated with R\&D expenditures, I use long term growth estimates instead of earnings forecasts. If analysts underestimate the long term growth in earnings in R\&D-intensive firms, they will have to revise their long term growth estimates upwards in the following years as realize their underestimation in the following years. This will result in positive association with R\&D intensity and revision in consensus (mean) analysts' forecast.

Next research question I investigate to what extent investors are mislead by analysts forecasts. If investors use analysts' forecasts to estimate future benefits of R\&D, they may be mislead by analysts' underestimation of future benefits of R\&D. Hence, analysts' underestimation might lead to mispricing of firms with heavy spending in R\&D.

\section{Research Design}

\subsection{Revision in Analysts' Forecasts and R\&D Intensity}

I first investigate whether analysts correctly estimate the future benefits associated with R\&D-intensive firms. Financial analysts are important source of information for investors. Gleason and Lee (2003) show that the price adjustment process is faster and more complete for firms with greater analyst following. Brennan et al. (1993) reports that stocks with greater analyst coverage react faster to market-wide common information. Hong et al. (2000) find that returns to momentum-based investment strategies are higher for firms with low levels of analyst coverage. Finally, Elgers et al. (2001) find that the price response to value relevant information in analyst earnings forecasts is less complete for firms with lower levels of analyst coverage. These studies suggest that financial markets heavily depend on the information provided by analysts.

When most of a firm's assets are intangible the valuation is much more difficult than tangible assets, because $R \& D$ expenditures are immediately expensed and balance sheet does not report R\&D capital of the firms. Thus, investors have to calculate the magnitude and profitability of R\&D capital of the firm by themselves. Moreover, reported earnings might be understated due to expensing of R\&D expenditures. Consequently, investors' dependence on analysts' information is greater in intangible firms. Barth, Kasznik, McNichols (2001) suggest that intangible intensive firms have more information asymmetry between managers and investors and more uncertainty about firm value than other firms. They conclude that in the absence of private information intermediaries, such as analysts, share price of high intangibles firms would be less precisely reflects fundamental values.

Considering the investors' dependence on analysts' information in R\&D-intensive firms, it is important to investigate whether financial analyst correctly estimates future benefits associated with R\&D-intensive firms. If future excess returns to $R \& D$ are due to mispricing of R\&D-intensive firms, then there are two possibilities for analysts' role in mispricing of these firms. The first possibility is that financial analysts underestimate the future benefits associated with $R \& D$ and misguide investors when they form their expectations about future benefits about R\&D. Alternatively, analysts are correctly estimating the future benefits associated with R\&D-intensive firms, but investors do not use the information in analysts' forecasts. To investigate these possibilities, I first investigate whether analysts correctly estimate future benefits associated with R\&D-intensive firms. If analysts 
underestimate future benefits associated with R\&D-intensive firms, they will revise their estimates upwards in following periods as they realize their underestimation. Thus, I observe an association between analysts' revision in following periods and R\&D-intensity. On the other hand if analysts correctly estimate future benefits, I should not observe any association between revision and R\&D intensity. I estimate following models to explore these conjectures.

$$
\begin{gathered}
R E V_{t+i}=\alpha_{0}+\alpha_{1}{ }^{*} R D E X P_{t}+\alpha_{2}{ }^{*} L B M_{t}+\alpha_{2}{ }^{*} \operatorname{LSIZE}_{t}+\alpha_{2}{ }^{*} L N U M_{t}+\varepsilon_{t+i} \\
R E V_{t+i}=\alpha_{0}+\alpha_{1} * R D C A P_{t}+\alpha_{2}{ }^{*} L B M_{t}+\alpha_{2}{ }^{*} \operatorname{LSIZE}_{t}+\alpha_{2}{ }^{*} L N U M_{t}+\varepsilon_{t+i} \\
R E V_{t+i}=\frac{L T G_{(t+1)+i}-L T G_{t+1}}{L T G_{t+1}}
\end{gathered}
$$

Where $R D E X P_{t}$ is R\&D expense (Compustat item \#46) divided by market value of equity at the end of fiscal year $t$. Market value of equity is share price times number of shares outstanding from CRSP at the end of December in year $t . R D C A P_{t}$ is $\mathrm{R} \& \mathrm{D}$ capital divided by market value of equity at the end of fiscal year $t . L T G_{t+1}$ is consensus (mean) long term growth estimate in May of year $t+1$. To ensure that financial information, such as earnings and $R \& D$ expenditures, is available when analysts estimate long term growth, I use the consensus analysts' forecast in May of year $t+1 . L T G_{t+i}$ is consensus (mean) long term growth estimate in May of year $(t+1)+i$. Therefore, $R E V_{t+i}$ shows percentage revision in consensus analysts' forecasts $i$ year after the initial forecast in May of year $t+1$. For example $R E V_{t+5}$ shows percentage revision in consensus analysts' forecast in May of $t+6$ relative to initial long term growth estimate in May of $t+1$. Percentage revision in consensus analysts' forecasts is calculated for periods ranging from one to five years. A very important reason for me to use long term growth estimate to measure the future benefits associated with $R \& D$ is that prior research documents that the benefits associated with R\&D investment is realized many years later (Lev \& Sougiannis, 1996). IBES states that financial analysts estimate long term growth in earnings for a period of three to five years. Therefore, it is more appropriate to use long term earnings growth estimates rather than earnings to estimate future benefits associated with $R \& D$ investment. Another important issue is that percentage revision is more appropriate than actual revision in reflecting relative revision in analysts' expectations.

Because a $1 \%$ revision in long term growth estimate for a firm with initial estimate of $4 \%$ would mean a $25 \%$ revision relative to the initial estimate whereas it would only mean a $5 \%$ revision for a firm with initial long term growth estimate of $20 \%$ (Note 1). Consistent with Lee, O'Brien and Sviramakrishnan (2004), I winsorize the tails of the dependent variable in equation (1) at $1 \% . L B M_{t}$ in equations (1) and (2) is log of book-to-market ratio. Book-to-market ratio is book value of equity (Compustat item \# 60) at the end of fiscal year $t$ divided by market value of equity. I include book-to-market ratio to control for value-glamour anomaly documented in prior literature (Doukas et al., 2002). CLS suggest that high R\&D expense to market value firms are past losers. Therefore, it might be possible that these firms are value firms with high book-to-market ratio. Consistent with value-glamour anomaly, I expect positive sign on $L B M_{t} . L S I Z E_{t}$ is $\log$ of market value of equity. We include market value of equity consistent with Core et al. (2006). $L N U M_{t}$ is $\log$ of number of analysts' forecasts used in calculation of consensus forecast. We add it to control for the information environment.

\subsection{Analysts' Forecasts Errors and Mispricing of $R \& D$}

In this section I investigate whether analysts' long term forecast errors lead to mispricing of R\&D. Specifically, I investigate whether investors correctly estimate the relationship between R\&D intensity and percentage revision in consensus analysts' forecasts. The Mishkin (1983) test was introduced to accounting literature by Sloan (1996) and widely used in many studies. My estimation procedure in Mishkin (1983) test consists of three steps. First, I estimate the association between percentage revision in consensus analysts' forecast over five years, $R E V$ ${ }_{t+5}$, and R\&D intensity. Second, I estimate the association between R\&D intensity and $R E V_{t+5}$ implicit in stock returns. Third, I compare the estimated coefficients from the above steps test whether market underestimates the effect of $R \& D$ on future earnings. I estimate following model to estimate the relationship between R\&D intensity and $R E V_{t+5}$.

$$
R E V_{t+5}=\alpha_{0}+\alpha_{1} R D_{t}+\varepsilon_{t}
$$

$R D_{t}$ is R\&D intensity. In above equation is either $R D E X P_{t}$ or $R D C A P_{t}$. In an efficient market all information is immediately incorporated into price. Hence, returns will be related to only unexpected information. Consequently, we assume that excess returns will be related to unexpected revision in analyst forecast, $U R E V_{t+5}$. 


$$
A V_{-} R E T_{t+5}=B_{0}+B_{1} U R E V_{t+5}+\varepsilon_{t+5}
$$

$A V R E T_{t+5}$ is size and book to market average excess returns over years $\mathrm{t}+1$ to $\mathrm{t}+5$. Calculation of excess returns is described in section 4.3. We can express unexpected revision as revision over $t+5$ mines expected revision at time t.

$$
U R E V_{t+5}=R E V_{t+5}-\text { Expectation at t of } R E V_{t+5}
$$

If we use equation (3) for expectation at t of $R E V_{t+5}$, we get following equation.

$$
A V_{-} R E T_{t+5}=B_{0}+B_{I}\left(R E V_{t+5}-\left(\alpha_{0}^{*}+\alpha_{1}^{*} R D_{t}\right)+\varepsilon_{t+5}\right.
$$

$\alpha_{1}^{*}$ in equation (6) shows the association between R\&D intensity and percentage revision in consensus analysts' forecast, $R E V_{t+5}$, implicit in prices. If investors correctly estimates the relationship between $R E V_{t+5}$ and $\mathrm{R} \& \mathrm{D}$ intensity, the coefficient estimate $\alpha_{1}^{*}$ in equation (4) should be equal to $\alpha_{1}$ that in equation (3) and vice versa.

\section{Data}

\subsection{Sample Characteristics}

My sample covers all NYSE, AMEX and NASDAQ firms covered in COMPUSTAT, CRSP and IBES between 1981 and 2004. To include in my sample, I require each observations to have financial statement data available in COMPUSTAT, return data in available in CRSP and long term growth estimates and realized long term growth available in IBES. The sample starts from 1981 because analyst long term forecast are available in IBES files after 1981. The last year in my sample is 2004 because I need 6 year-ahead return data to calculate 5 -year-ahead returns. Financial statement data is obtained from COMPUSTAT, monthly return data from CRSP and analyst long term growth estimates are obtained from IBES. I use market value of equity as deflator in calculation of R\&D expenditures to market value of equity. To eliminate the impact of small deflator, I deleted the observations with market value of equity less than 100 million. To eliminate the impact of extreme observations, I also delete observation with R\&D to market value of equity greater than $500 \%$ and book value less than zero. This yields a final sample of 16,515 observations.

\subsection{Descriptive Statistics for $R \& D$ and Non-R\&D Firms}

Table 1 presents descriptive statistics for R\&D and non R\&D firms. $42 \%$ of my sample consists of R\&D firm-year observations. The mean book-to-market ratio for non-R\&D firms is greater than R\&D firms. This suggests that R\&D firms have better growth opportunities (Simith \& Watts (1992)). The mean (median) market value of equity for R\&D firms 4,402 million (891 million) greater than 2,341 million (681 million) for non-R\&D firms. However, mean (median) total assets for R\&D firms is 4,582 million (733 million) less than 6,788 million (1,041 million) for non-R\&D firms. This indicates that even though R\&D firms have smaller tangible capital, their market value is greater than non-R\&D firms. This finding implies existence of intangible capital in R\&D-intensive firms. The mean (median) earnings-to-price ratio for R\&D firms is 5.11\% (5.55\%) significantly smaller than $6.50 \%$ (6.39) for non-R\&D firms. This is because market value of equity for R\&D firms is greater non-R\&D firms. However, mean (median) return on asset for R\&D firms are 7.35\% (7.30\%) greater than 5.49\% non-R\&D firms. This is because non-R\&D firms have larger total assets than R\&D firms. The mean (median) $R \& D$ expenditures to market value of equity for R\&D firms is $4.75 \%$ (2.94\%). The mean (median) R\&D capital to market value of equity is $10.67 \%$ (6.47\%), more than twice that of R\&D expenditures to market value of equity. R\&D capital is calculated by accumulating the unamortized portion of previous years' R\&D expenditures. Amortization rates are obtained from Lev and Sougiannis (1996).

Analysts' consensus long term growth estimates for R\&D firms are more optimistic than non-R\&D firms. The mean (median) forecast error in long term growth estimates for R\&D firms is -8.02\% (7.18\%) significantly more negative than $-6.27 \%(-4.50 \%)$ for non-R\&D firms. However, the mean (median) percentage revision in analysts' consensus long term growth estimates for R\&D firms is $-3.87 \%(-7.91 \%)$ not significantly different from $-3.66 \%(-9.09 \%)$ for non-R\&D firms. This suggests analysts continue to hold high earnings growth expectations for R\&D firms even though their realized earnings growth turned out to be less than what they expected. 
Table 1. Descriptive Statistics for R\&D and non-R\&D firms

\begin{tabular}{|c|c|c|c|c|c|c|}
\hline & \multicolumn{3}{|l|}{ Mean } & \multicolumn{3}{|l|}{ Median } \\
\hline & Non-R\&D & R\&D & $\begin{array}{l}\text { Difference = R\&D } \\
\text { minus non-R\&D } \\
\text { p-value of t-stat }\end{array}$ & Non-R\&D & R\&D & $\begin{array}{l}\text { Difference }=R \& D \\
\text { minus non-R\&D } \\
\text { p-value of Z-stat }\end{array}$ \\
\hline R\&D to market value of equity & 0 & 0.0473 & 0.00 & 0 & 0.0293 & 0.00 \\
\hline R\&D capital to market value of equity & 0 & 0.1062 & 0.00 & 0 & 0.0647 & 0.00 \\
\hline Return on Asset & 0.0549 & 0.0735 & 0.00 & 0.0466 & 0.0730 & 0.00 \\
\hline Earnings-to-Price & 0.0650 & 0.0515 & 0.00 & 0.0640 & 0.0556 & 0.00 \\
\hline Book-to-market & 0.5752 & 0.4861 & 0.00 & 0.5152 & 0.4209 & 0.00 \\
\hline Market value of equity & 2341 & 4404 & 0.00 & 681 & 891 & 0.00 \\
\hline Earnings & 133 & 214 & 0.00 & 40 & 42 & 0.00 \\
\hline R\&D capital & 0 & 349 & 0.00 & 0 & 55 & 0.00 \\
\hline R\&D expenditures & 0 & 156 & 0.00 & 0 & 25 & 0.00 \\
\hline Sales revenue & 2359 & 3916 & 0.00 & 758 & 862 & 0.00 \\
\hline Total assets & 6788 & 4583 & 0.00 & 1041 & 733 & 0.00 \\
\hline Long term growth estimate $\left(L T G_{t+1}\right)$ & 14.11 & 16.44 & 0.00 & 13.10 & 14.40 & 0.00 \\
\hline $\begin{array}{l}\text { Forecast error in long term growth } \\
\text { estimates }\left(F E_{t}\right)\end{array}$ & -6.27 & -8.02 & 0.00 & -4.50 & -7.18 & 0.00 \\
\hline $\begin{array}{l}\text { Percentage revision in analysts' long term } \\
\text { growth estimates }\left(R E V_{t+5}\right)\end{array}$ & -0.0366 & -0.0387 & 0.76 & -0.0909 & -0.0791 & 0.13 \\
\hline Number of analysts' forecasts & 6.45 & 7.54 & 0.00 & 5 & 6 & 0.00 \\
\hline Number of firm-year observations (N) & 7,793 & 5,722 & & & & \\
\hline
\end{tabular}

\subsection{R\&D Intensity and Future Excess Returns}

In this section I investigate the relationship between R\&D intensity and future excess returns. As discussed above prior research documents that R\&D expenditures generate future excess returns (Lev \& Sougainnis, 1996; Ciftci et al., 2011; Ciftci \& Cready, 2011, etc.). I want to first verify this established result with our data. Panel A of Table 2 reports 1 to 5-year-ahead size and book-to-market-adjusted excess returns for portfolios formed based on $R \& D$ expenditures to market value of equity. The excess returns are size and book-to-market adjusted returns calculated from May to April of next year using companion portfolio approach as in CLS. Following CLS each firm in the sample is assigned to a companion portfolio based on its ranking by size and book-to-market. For the companion portfolio, the book-to-market ratios are classified into five equal groups at the end of April each year; the size breakpoints are determined by classifying the NYSE companies into five equal groups in April each year. The group representing the smallest size is further divided into two equal groups. Thus, I have five groups for the book-to-market ratio and six groups for size to determine the companion portfolio of book-to-market and size that each company belongs. The monthly excess returns are then computed as the difference the firm's monthly returns minus the companion portfolio's value-weighted monthly returns. The annual excess returns are obtained by cumulating the monthly excess returns.

Since this study investigates the relation between long term growth estimate and future excess returns, I report returns from first year after portfolio formation to until fifth year. The first column reports non-R\&D firms. Non-R\&D firms generates excess returns of $1.6 \%$ over 5 -year after portfolio formation (an average of $1 \%$ in first 3 years). This is slightly greater $0.26 \%$, the average return over 3-years in CLS. However my sample is smaller than CLS because I require each observation to have long term growth estimate and realized long term growth in IBES files. The first portfolio, the lowest intensity of portfolio, does not generate future excess returns. However the average annual excess returns over 5-year after portfolio formation in portfolios 2, 3 and 4 are significant and positive. Moreover, the average annual future excess returns in fourth portfolio reached to the magnitude of $10 \%$ (p-value $<0.01$ ). This finding is consistent with CLS, Chambers et al. (2002) and Lev and Sougiannis (1996) suggesting that firms with high $R \& D$ expenditures to market value of equity generates future excess returns. Panel B reports future excess returns for R\&D capital to market value portfolios. The results are similar to those in Panel A: Future excess returns are increasing with R\&D intensity. 
Table 2. Future Excess Returns to R\&D Portfolios

PANEL A: Excess Returns for Portfolios Based on R\&D Expenditures/MVE

\begin{tabular}{llllll}
\hline \multirow{2}{*}{ Years Following the Investment Date } & \multirow{2}{*}{ Non-R\&D } & \multicolumn{4}{c}{ Portfolios Based on R\&D Expenditures / MVE } \\
\cline { 3 - 6 } & & 1 & 2 & 3 & 4 \\
\hline Number of firms in the portfolio & 7793 & 1425 & 1432 & 1439 & 1426 \\
1 year ahead & -0.0014 & $0.0273^{* *}$ & $0.0398^{* * *}$ & $0.0967^{* * *}$ & $0.1452^{* * *}$ \\
2 years ahead & $0.0077^{*}$ & 0.0047 & $0.0355^{* * *}$ & $0.0574^{* * *}$ & $0.1235^{* * *}$ \\
3 years ahead & $0.0256^{* * *}$ & 0.0042 & $0.0275^{* *}$ & $0.0238^{* *}$ & $0.0928^{* * *}$ \\
4 years ahead & $0.0233^{* * *}$ & -0.0003 & $0.0318^{* * *}$ & $0.0576^{* * *}$ & $0.0555^{* * *}$ \\
5 years ahead & $0.0258^{* * *}$ & 0.0042 & $0.0297^{* *}$ & $0.0225^{*}$ & $0.0951^{* * *}$ \\
Average over 5 years & $0.0162^{* * *}$ & 0.0080 & $0.0323^{* * *}$ & $0.0516^{* * *}$ & $0.1024^{* * *}$ \\
\hline
\end{tabular}

PANEL B: Excess Returns for Portfolios Based on R\&D Capital/MVE

\begin{tabular}{lllll}
\hline \multirow{2}{*}{ Years Following the Investment Date } & \multicolumn{4}{c}{ Portfolios Based on R\&D Capital / MVE } \\
\cline { 2 - 5 } & 1 & 2 & 3 & 4 \\
\hline Number of firms in the portfolio & 1425 & 1433 & 1438 & 1426 \\
1 year ahead & 0.0114 & $0.0567^{* * *}$ & $0.0819^{* * *}$ & $0.1591^{* * *}$ \\
2 years ahead & -0.0071 & 0.0139 & $0.1007^{* * *}$ & $0.1132^{* * *}$ \\
3 years ahead & 0.0010 & 0.0180 & $0.0454^{* * *}$ & $0.0837^{* * *}$ \\
4 years ahead & -0.0056 & $0.0295^{* * *}$ & $0.0540^{* * *}$ & $0.0667^{* * *}$ \\
5 years ahead & 0.0003 & $0.0211^{*}$ & $0.0441^{* * *}$ & $0.0859^{* * *}$ \\
Average over 5 years & 0.0000 & $0.0278^{* * *}$ & $0.0652^{* * *}$ & $0.1017^{* * *}$ \\
\hline
\end{tabular}

Note: ${ }^{* * *},{ }^{* *},{ }^{*}$ significantly different from zero at the $1 \%, 5 \%$, and $10 \%$ level, respectively.

\section{Results}

\subsection{R\&D Intensity and Revision in Analysts' Long Term Growth Estimates}

\subsubsection{Univariate Tests}

Panel A of Table 3 reports percentage revision in analysts' consensus forecast over $i$ years, $R E V_{t+i}$, and forecast error, $F E_{t}$, for portfolios based on $\mathrm{R} \& \mathrm{D}$ expenditures to market value of equity. The percentage revision in consensus analysts' forecast after one year portfolio formation, $R E V_{t+1}$, in the lowest $\mathrm{R} \& \mathrm{D}$ expense to market value portfolio, portfolio 1 , is $-1.30 \%$, whereas it is $1.13 \%$ in portfolio 4 , the highest $R \& D$ intensity portfolio. The difference in mean value of $R E V_{t+1}$ between portfolios 1 and 4 is $2.43 \%$. The difference in mean value of $R E V_{t+2}$ between these portfolios increases to $6.15 \%$. Finally, the difference between these two portfolios in mean value of $R E V_{t+5}$, revision in fifth year, increases to 9.89\%. This finding suggest that even though analysts revise their long term growth estimates downward in portfolio 1 after their initial estimate, they revise their estimates upward in portfolio 4. Even though, as shown in Table 1, there is no significant difference in the mean value of $R E V_{t+5}$ between $\mathrm{R} \& \mathrm{D}$ and non-R\&D firms for all $\mathrm{R} \& \mathrm{D}$ firms, the mean value of $R E V_{t+5}$ in portfolio 4 is greater than non-R\&D firms. Moreover, the mean value of $R E V_{t+5}$ in portfolio 1 is smaller than non-R\&D firms.

More interestingly, the mean consensus analysts' long term growth forecast is around $16 \%$; approximately similar for both portfolios 1 and 4 . However, the mean value of realized long term earnings growth for portfolio 1 is $5.61 \%$ whereas it is $11.57 \%$ for portfolio 4 . This result suggest that even though analysts' expect similar long term growth for the highest and lowest $\mathrm{R} \& \mathrm{D}$ intensity portfolios, the realized long term growth is much smaller in the lowest one.

Panel B of Table 3 reports results for portfolios based on R\&D capital to market value of equity. The results are even stronger for R\&D capital to market value of equity portfolios. Overall, the results in Table 3 suggest that analysts overestimate the long term earnings growth in low R\&D intensity portfolio but underestimate it in high R\&D intensity portfolio. However, the book-to-market ratio in portfolio 4 of both R\&D expenditures to market value of equity and R\&D capital to market value of equity is around 0.64 much higher than 0.40 that in portfolio 1. This indicates that high R\&D intensity portfolios have high book-to-market ratio. Therefore, the above findings might be due to well-documented value-glamour anomaly. Moreover, market value of equity in the fourth portfolio is only 2,824 million compared to 5,607 million in first portfolio. Thus, I cannot make unambiguous conclusions without controlling book-to-market and size. 
Table 3. Long Term Forecast Errors for R\&D Portfolios

PANEL A: Descriptive Statistics for R\&D Expenditures to Market Value Portfolios

\begin{tabular}{llllll}
\hline & \multirow{4}{*}{ Non-R\&D D Portfolios Based on R\&D Expenditures / MVE } \\
\cline { 3 - 6 } & & 1 & 2 & 3 & 4 \\
\hline R\&D to market value of equity & 0 & 0.0079 & 0.0214 & 0.0421 & 0.1181 \\
R\&D capital to market value of equity & 0 & 0.0185 & 0.0496 & 0.0976 & 0.2594 \\
Long term growth estimate $\left(L T G_{t+1}\right)$ & 14.12 & 16.43 & 16.52 & 16.64 & 16.16 \\
Forecast error in analysts' long term growth estimates $\left(F E_{t}\right)$ & -6.27 & -10.82 & -9.53 & -7.14 & -4.60 \\
Realized growth in earnings & 7.85 & 5.61 & 6.99 & 9.50 & 11.57 \\
$\left(R E V_{t+5}\right)$ & -0.0366 & -0.0857 & -0.0532 & -0.0284 & 0.0133 \\
$\left(R E V_{t+4}\right)$ & -0.0232 & -0.0685 & -0.0552 & -0.0205 & 0.0240 \\
$\left(R E V_{t+3}\right)$ & -0.0093 & -0.0537 & -0.0377 & -0.0127 & 0.0208 \\
$\left(R E V_{t+2}\right)$ & -0.0035 & -0.0394 & -0.0164 & -0.0155 & 0.0221 \\
$\left(R E V_{t+1}\right)$ & 0.0123 & -0.0130 & -0.0097 & -0.0077 & 0.0113 \\
Market value of equity & 2341 & 5191 & 5162 & 4433 & 2824 \\
Book-to-market ratio & 0.58 & 0.41 & 0.42 & 0.47 & 0.64 \\
Number of analysts' forecasts & 6.45 & 7.45 & 7.64 & 7.80 & 7.27 \\
\hline
\end{tabular}

PANEL A: Descriptive Statistics for R\&D Capital to Market Value Portfolios

\begin{tabular}{|c|c|c|c|c|}
\hline & \multicolumn{4}{|c|}{ Portfolios Based on R\&D Capital / MVE } \\
\hline R\&D to market value of equity & 0.0085 & 0.0223 & 0.0431 & 0.1156 \\
\hline R\&D capital to market value of equity & 0.0172 & 0.0472 & 0.0949 & 0.2658 \\
\hline Long term growth estimate $\left(L T G_{t+1}\right)$ & 17.04 & 16.90 & 16.48 & 15.33 \\
\hline Forecast error in analysts' long term growth estimates $\left(F E_{t}\right)$ & -11.41 & -9.55 & -7.37 & -3.77 \\
\hline$\left(R E V_{t+5}\right)$ & -0.1011 & -0.0498 & -0.0277 & 0.0246 \\
\hline$\left(R E V_{t+4}\right)$ & -0.0841 & -0.0479 & -0.0252 & 0.0369 \\
\hline$\left(R E V_{t+3}\right)$ & -0.0633 & -0.0408 & -0.0114 & 0.0321 \\
\hline$\left(R E V_{t+2}\right)$ & -0.0464 & -0.0235 & -0.0062 & 0.0268 \\
\hline Number of analysts' forecasts & 7.55 & 7.44 & 7.61 & 7.56 \\
\hline
\end{tabular}

\subsection{Regressions Results for the Relationship between $R \& D$}

Panel A of Table 4 reports regression results of equation (1) where percentage revision in consensus analyst forecast is regressed on R\&D expenditures to market value of equity and control variables. The standard errors are corrected for heteroscedasticity and autocorrelation based on Huber-White procedure (Petersen, 2009). The first column reports regression results when the dependent variable is $R E V_{t+l}$, the percentage revision in consensus analysts' forecast one year after portfolio formation. The coefficient estimate of $R D E X P_{t}$ is insignificant, suggesting that there is not significant relationship between R\&D intensity and analysts' forecast revision in first year after portfolio formation. The intercept is also insignificant indicating that there is no significant revision for non-R\&D firms as well. The second column reports regression results when the dependent variable is $R E V_{t+2}$. The coefficient estimate of $R D E X P_{t}$ is 0.2107 ( $p$-value $<0.01$ ). If a firm has $10 \%$ of $\mathrm{R} \& \mathrm{D}$ expenditures to market value of equity, the $R E V_{t+2}$ for that firm would be $2.1 \%(=0.2107 * 0.10)$ higher than that for non-R\&D firms. This finding is consistent the results in Table 3 indicating that revision analysts' long term growth estimates increases with $R \& D$ intensity. The results here indicates that financial analysts underestimate long term growth in earnings in high R\&D firms and correct their underestimation starting with two years after their initial forecasts. The intercept is negative -0.0569 (p-value $<0.01)$, indicating analysts revise downward their long term growth estimates for non-R\&D firms. The $t$-value of $L B M_{t}$ is 12.26, suggesting that the strongest explanatory variable in the regression is log of book-to-market ratio, underlining the importance of book-to-market effect. The results are consistent with value-growth anomaly documented in prior studies (Doukas et al., 2002). The log of market value of equity, $L S I Z E_{t}$ is positive and significant suggesting that analyst forecast revision is less negative for larger firms. The log of number of analyst forecasts, $L N U M_{t}$, is negative and significant. 
The next three columns reports regression results where the dependent variables are $R E V_{t+3}, R E V_{t+4}$ and $R E V_{t+5}$ respectively. The coefficient estimates for $R D E X P_{t}$ are $0.2588,0.3288$ and 0.3587 respectively and all of them are significant at $1 \%$. These results indicates that the association between $\mathrm{R} \& \mathrm{D}$ intensity $R D E X P_{t}$ and the percentage revision in consensus analysts' long term growth estimates increase as revision period increase. The percentage revision over 3-year period is greater than 2-year period and 4-year period is greater than 3-year period. Finally, the revision over 5-year period is only slightly greater than 4-year period suggesting that most of the revision is realized in first four years and there is relatively small revision in the fifth year.

Panel B reports regression results where I measure R\&D intensity with R\&D capital to market value of equity, $R D C A P_{t}$. Similar to Panel A, starting from second year there is a positive association between $R D C A P_{t}$ and percentage revision in analysts' forecast. Moreover, the t-value value of $R D C A P_{t}$ is greater than that of $R D E X P_{t}$ in Panel A of Table 4, suggesting that the association between R\&D intensity and percentage revision in analysts' forecast long term growth estimates is stronger when I measure R\&D intensity of firms with R\&D capital.

In untabulated results here, I replicate the above regression by using ranks of variables instead of actual variables. I assign the both dependent and independent variables in equation (1) and (2) into quartiles. The results are similar to those of Table 4 . There is a positive association between R\&D intensity and percentage revision in analysts' long term growth estimates regardless of whether I measure R\&D intensity with R\&D capital to market value of equity or with R\&D expenditures to market value of equity. Moreover, the positive association between R\&D intensity and percentage analyst forecast revision is realized starting from 1-year after portfolio formation and continues until 5-year.

Table 4. Regression of R\&D on Revision on Long Term Growth Estimates

PANEL A: Regression of $R E V_{t+i}$ on $R \& D$ Expenditures to Market Value of Equity (Equation (1))

\begin{tabular}{|c|c|c|c|c|c|c|c|c|c|c|}
\hline \multirow[b]{2}{*}{ Dependent V. } & \multicolumn{2}{|l|}{$R E V_{t+1}$} & \multicolumn{2}{|l|}{$R E V_{t+2}$} & \multicolumn{2}{|l|}{$R E V_{t+3}$} & \multicolumn{2}{|l|}{$R E V_{t+4}$} & \multicolumn{2}{|l|}{$R E V_{t+5}$} \\
\hline & $\begin{array}{l}\text { Coefficient } \\
\text { Estimate }\end{array}$ & t-value & $\begin{array}{l}\text { Coefficient } \\
\text { Estimate }\end{array}$ & t-value & $\begin{array}{l}\text { Coefficient } \\
\text { Estimate }\end{array}$ & t-value & $\begin{array}{l}\text { Coefficient } \\
\text { Estimate }\end{array}$ & $\mathrm{t}$-value & $\begin{array}{l}\text { Coefficient } \\
\text { Estimate }\end{array}$ & t-value \\
\hline Intercept & -0.0042 & -0.20 & -0.0569 & $-4.49^{* * *}$ & -0.0691 & $-4.19^{* * *}$ & -0.0761 & $-3.95^{* * *}$ & -0.0653 & $-3.04^{* * *}$ \\
\hline$R D E X P_{t}$ & 0.0372 & 0.66 & 0.2107 & $3.52^{* * *}$ & 0.2588 & $3.82^{* * *}$ & 0.3288 & $4.15^{* * *}$ & 0.3579 & $3.51^{* * *}$ \\
\hline$L B M_{t}$ & 0.0400 & $3.96^{* * *}$ & 0.0535 & $12.26^{* * *}$ & 0.0796 & $14.11^{* * *}$ & 0.1000 & $15.94^{* * *}$ & 0.1167 & $16.83^{* * *}$ \\
\hline$L S I Z E_{t}$ & 0.0199 & $6.17^{* * *}$ & 0.0259 & $10.15^{* * *}$ & 0.0318 & $9.59^{* * *}$ & 0.0344 & $8.86^{* * *}$ & 0.0321 & $7.42^{* * *}$ \\
\hline$L N U M_{t}$ & -0.0569 & $-4.00^{* * *}$ & -0.0534 & $-4.52^{* * *}$ & -0.0620 & $-9.81^{* * *}$ & -0.0667 & $-9.01^{* * *}$ & -0.0627 & $-7.74^{* * *}$ \\
\hline $\mathrm{R}^{2}$ & 0.0040 & & 0.0279 & & 0.0395 & & 0.0499 & & 0.0559 & \\
\hline \multicolumn{11}{|c|}{ PANEL B: Regression Results with R\&D Capital to Market Value of Equity (Equation (2)) } \\
\hline \multirow[b]{2}{*}{ Dependent V. } & $R E V_{t+1}$ & & $R E V_{t+2}$ & & $R E V_{t+3}$ & & $R E V_{t+4}$ & & $R E V_{t+5}$ & \\
\hline & $\begin{array}{l}\text { Coefficient } \\
\text { Estimate }\end{array}$ & t-value & $\begin{array}{l}\text { Coefficient } \\
\text { Estimate }\end{array}$ & t-value & $\begin{array}{l}\text { Coefficient } \\
\text { Estimate }\end{array}$ & t-value & $\begin{array}{l}\text { Coefficient } \\
\text { Estimate }\end{array}$ & t-value & $\begin{array}{l}\text { Coefficient } \\
\text { Estimate }\end{array}$ & t-value \\
\hline Intercept & -0.0108 & -0.52 & -0.0587 & $-4.65^{* * *}$ & -0.0716 & $-4.35^{* * *}$ & -0.0793 & $-4.11^{* * *}$ & -0.0691 & $-3.21^{* * *}$ \\
\hline$R D C A P_{t}$ & 0.0324 & 1.11 & 0.1305 & $4.47^{* * *}$ & 0.1669 & $4.81^{* * *}$ & 0.2097 & $5.58^{* * *}$ & 0.2338 & $5.41^{* * *}$ \\
\hline$L B M_{t}$ & 0.0346 & $3.39^{* * *}$ & 0.0525 & $11.92^{* * *}$ & 0.0782 & $13.75^{* * *}$ & 0.0984 & $15.55^{* * *}$ & 0.1148 & $16.43^{* * *}$ \\
\hline$L S I Z E_{t}$ & 0.0196 & $5.86^{* * *}$ & 0.0259 & $10.15^{* * *}$ & 0.0318 & $9.59^{* * *}$ & 0.0345 & $8.86^{* * *}$ & 0.0322 & $7.42^{* * *}$ \\
\hline$L_{N U M_{t}}$ & -0.0553 & $-3.76^{* * *}$ & -0.0538 & $-10.37^{* * *}$ & -0.0626 & $-9.90^{* * *}$ & -0.0675 & $-9.10^{* * *}$ & -0.0636 & $-7.84^{* * *}$ \\
\hline $\mathrm{R}^{2}$ & 0.0040 & & 0.0290 & & 0.0409 & & 0.0518 & & 0.0581 & \\
\hline
\end{tabular}

Notes: This table reports the estimation results of following equations: $R E V_{t+i}=\alpha_{0}+\alpha_{1} * R D E X P_{t}+\alpha_{2} * L B M_{t}+\alpha_{2} * L S I Z E_{t}+\alpha_{2} * L N U M_{t}+$ $\varepsilon_{t+i} ; R E V_{t+i}=\alpha_{0}+\alpha_{1} * R D C A P_{t}+\alpha_{2} * L B M_{t}+\alpha_{2} * L S I Z E_{t}+\alpha_{2} * L N U M_{t}+\varepsilon_{t+i}$.

\subsection{Analysts' Forecasts Errors and Mispricing of R\&D}

In this section I present the estimation results of Miskin test from equation (3) and (4). The estimation results with R\&D expenditures to market value of equity, $R D E X P_{t}$, are in Panel A of Table 5. The coefficient estimate of $\alpha_{l}$ in forecasting equation is 0.4804 ( $p$-value $<0.01$ ), indicating that there is a positive relationship between $\mathrm{R} \& \mathrm{D}$ expenditures to market value of equity and $R E V_{t+5}$. However, the coefficient estimate of $\alpha_{1}^{*}$ in valuation equation is -5.3040 ( $p$-value $<0.01$ ), suggesting that investors price $R \& D$ as if there is negative relationship between R\&D intensity and $R E V_{t+5}$. Moreover, the difference between $\alpha_{l}$ and $\alpha_{1}^{*}$ is statistically significant $(p$-value $<0.01)$ (Note 2). The estimation results are similar with R\&D capital to market value, $R D C A P_{t}$, in Panel $B$ of Table 5. Investors underestimate the relationship between R\&D intensity and percentage revision in 
consensus analysts' forecast, $R E V_{t+5}$. Overall, the results in Table 5 suggest that analysts underestimate the future benefits of R\&D but investors are not aware of this underestimation and use these biased estimates in forming their expectations about future benefits of R\&D. Hence, mispricing of R\&D might be affected from the bias in analysts' forecasts about R\&D.

Table 5. Mishkin Test Results

PANEL A: Estimation with R\&D Expenditures to Market Value of Equity $\left(R D E X P_{t}\right)$

\begin{tabular}{llllll}
\hline & $\alpha_{1}$ & $B_{0}$ & $B_{1}$ & $\alpha_{0}^{*}$ & $\alpha_{1}^{*}$ \\
\hline Coefficient Estimate & 0.4804 & 0.0142 & 0.0394 & -4.8671 & -5.3040 \\
t-value & $7.54^{* * *}$ & $1.72^{*}$ & $6.21^{* * *}$ & $-6.03^{* * *}$ & $-9.66^{* * *}$ \\
\hline Test of market Efficiency: $\alpha_{1}=\alpha_{1}^{*}$ & & & & \\
Likelihood Ratio statistic $=174.78(p$-value $<0.01)$ & & & \\
\hline PANEL B Estimation with R\&D Capital to Market Value of Equity $(\mathbf{R D C A P})$ & &
\end{tabular}

PANEL B: Estimation with R\&D Capital to Market Value of Equity $\left(R D C A P_{t}\right)$

\begin{tabular}{llllll}
\hline & $\alpha_{1}$ & $B_{0}$ & $B_{1}$ & $\alpha_{0}^{*}$ & $\alpha_{1}^{*}$ \\
\hline Coefficient Estimate & 0.3002 & 0.0165 & 0.0422 & -3.7021 & -2.28 \\
t-value & $16.88^{* * *}$ & $1.85^{*}$ & $7.63^{* * *}$ & $-4.75^{* * *}$ & $-8.97^{* * *}$ \\
\hline
\end{tabular}

Test of market Efficiency: $\alpha_{1}=\alpha_{1}^{*}$

Likelihood Ratio statistic $=158.00(p$-value $<0.01)$

Note: ${ }^{* * *},{ }^{* *},{ }^{*}$ significantly different from zero at the $1 \%, 5 \%$, and $10 \%$ level, respectively. The above tables report the estimation results of following equations: $R E V_{t+5}=\alpha_{0}+\alpha_{1} R D_{t}+\varepsilon_{t} ; A V_{-} R E T_{t+5}=B_{0}+B_{l}\left(R E V_{t+5}-\left(\alpha_{0}^{*}+\alpha_{1}^{*} R D_{t}\right)\right)+\varepsilon_{t+5}$.

\section{Conclusion}

This paper investigates whether future excess returns to R\&D-intensive firms documented in prior literature is due to mispricing of R\&D expenditures or compensation for additional risk associated with R\&D expenditures. I investigate revision in analysts' long term growth estimates for R\&D-intensive firms because investors heavily depend on analysts' information for these firms (Barth et al., 2001). Hence, analysts' bias about future benefits of R\&D might lead to investor bias. I find that analysts underestimate earnings long term growth for R\&D-intensive firms and correct their underestimation in the following years. I also find that investors do not correct analysts' underestimation of future benefits of R\&D. This result suggests that mispricing of R\&D might be due to analysts' bias in estimating future benefits of R\&D. The findings in this paper, together with the results of prior studies, indicate that future excess returns to R\&D are due to both mispricing and higher risk associated with R\&D. Hence, greater risk associated with R\&D is not the only underlying reason for the excess returns.

In this study we focus on revision in analyst forecast. However, given the great level of uncertainty regarding $R \& D$ investment, it could be interesting to see whether the

dispersion in analysts' forecasts changes through the years. Ciftci et al. (2011) document that dispersion in analyst forecast for high industry-adjusted R\&D capital to sales group is greater than low group. Moreover, they show that high industry adjusted R\&D to sales group generates larger excess returns compared to low group even after controlling for dispersion in analyst forecast. Hence, their results suggest that future excess returns cannot be attributable solely to dispersion. However, they do not investigate whether dispersion in analysts' forecast decreases or increases in subsequent years. Hence, it might be interesting to investigate the issue in future research.

\section{References}

Aboody, D., \& Lev, B. (1998). The value relevance of intangibles: The case of software capitalization. Journal of Accounting Research, 36, 161-191. http://dx.doi.org/10.2307/2491312

Ali, A., Ciftci, M., \& Cready, W. M. (2012). Market underestimation of the implications of R\&D increases for future earnings: the U.S. evidence?. Journal of Business Finance and Accounting, 39, 289-314. http://dx.doi.org/10.1111/j.1468-5957.2012.02282.x

Barron, O. E., Byard, D., \& Oliver, K. (2002). Changes in Analysts' Information around Earnings Announcements. Accounting Review, 77, 821-847. http://dx.doi.org/10.2308/accr.2002.77.4.821

Barth, M. E., Kasznik, R., \& McNichols, M. F. (2001). Analyst Coverage and Intangible Assets. Journal of Accounting Research, 39, 1-34. http://dx.doi.org/10.1111/1475-679X.00001 
Brennan, M. J., Jegadeesh, N., \& Swaminathan, B., (1993). Investment analysis and the adjustment of stock prices to common information. Review of Financial Studies, 6(4). http://dx.doi.org/10.1093/rfs/6.4.799

Chambers, D., Jennings, R., \& Thompson II, R. B. (2002). Excess returns to R\&D-Intensive Firms. Review of Accounting Studies, 7, 133-158. http://dx.doi.org/10.1023/A:1020217817156

Chan, L., Lakonishok, J., \& Sougiannis, T. (2001). The stock market valuation of research and development expenditures. Journal of Finance, 56(2), 431-457.

Ciftci, M., \& Cready. W. M. (2011). R\&D scale effects in earnings and returns. Journal of Accounting and Economics, 52, 62-80. http://dx.doi.org/10.1016/j.jacceco.2011.02.003

Ciftci, M., Lev, B., \& Radhakrishnan, S. (2011). Is R\&D mispriced or properly risk-adjusted?. Journal of Accounting, Auditing \& Finance, 26, 81-116. http://dx.doi.org/10.1177/0148558X11400581

Core, J. E., Guay, W. R., \& Rusticus, T. O. (2006). Does weak governance cause weak stock returns? An examination of firm operating performance and Investors' expectations. Journal of Finance, 61, 655-687. http://dx.doi.org/10.1111/j.1540-6261.2006.00851.x

Darrough, M. N., \& Ye, J. (2007). Valuation of loss firms in a knowledge-based economy. Review of Accounting Studies, 12, 61-93. http://dx.doi.org/10.1007/s11142-006-9022-z

Doukas, J. A., Kim, C., \& Pantzalis, C. (2002). A Test of the Errors-in-Expectations Explanation of the Value/Glamour Stock Returns Performance: Evidence from Analysts’ Forecasts. Journal of Finance, 57, 2143-2165. http://dx.doi.org/10.1111/1540-6261.00491

Eberhart, A. C., Maxwell, W. F., \& Siddique, A. R. (2004). An examination of long-term abnormal stock returns and operating performance following R\&D increases. Journal of Finance, 59, 623-651. http://dx.doi.org/10.1111/j.1540-6261.2004.00644.x

Eberhart, A. C., Maxwell, W. F., \& Siddique, A. R. (2008). A reexamination of the tradeoff between the future benefit and riskiness of R\&D increases. Journal of Accounting Research, 46, 27-53. http://dx.doi.org/10.1111/j.1475-679X.2007.00264.x

Elgers, T. P., Lo, M. H., \& Pfiefer Jr., R. J. (2001). Analysts’ vs. investors’ weightings of accruals in forecasting annual earnings. Journal of Accounting and Public Policy, 22, 255-280. http://dx.doi.org/10.1016/S0278-4254(03)00022-X

Fama, E. F., \& MacBeth, J. (1973). Risk, return and equilibrium: Empirical tests. Journal of Political Economy, 81, 607-636. http://dx.doi.org/10.1086/260061

Gleason, C. A., \& Lee, C. M. (2003). Analyst Forecast Revisions and Market Price Discovery. Accounting Review, 78, 193-226. http://dx.doi.org/10.2308/accr.2003.78.1.193

Ho, Y. K., Xu, Z., \& Yap, C. M. (2004). R\&D investment and systematic risk. Accounting and Finance, 44, 393-418. http://dx.doi.org/10.1111/j.1467-629x.2004.00116.x

Hong, H., Lim, T., \& Stein, J. C. (2000). Bad News Travels Slowly: Size. Analyst Coverage, and the Profitability of Momentum Strategies. Journal of Finance, 55, 265-295. http://dx.doi.org/10.1111/0022-1082.00206

Kimbrough, M. D. (2007). The influences of financial statement recognition and analyst coverage on the market's valuation of R\&D capital. The Accounting Review, 82, 1195-1225. http://dx.doi.org/10.2308/accr.2007.82.5.1195

Kothari, S. P., Laguerre, T. E., \& Leone, J. A. (2002). Capitalization versus expensing: Evidence on the uncertainty of future earnings from capital expenditures versus R\&D outlays. Review of Accounting Studies, 7, 355-382. http://dx.doi.org/10.1023/A:1020764227390

La Porta, R. (1996). Expectations and the cross-section of stock returns. Journal of Finance, 51, 1715-1742.

Lakonishok, J., Shleifer, A., \& Vishny, R. W. (1994). Contrarian investment, extrapolation, and risk. Journal of Finance, 49, 1541-1578.

Lee, B., O’Brien, J., \& Sivaramakrishnan, K. (2004). An analysis of financial analysts' optimism in Long term growth forecasts. Working paper.

Lev, B. (2004). Sharpening the intangible edge. Harvard Business Review, 82, 109-116. 
Lev, B., \& Sougiannis, T. (1996). The capitalization, amortization and value-relevance of R\&D. Journal of Accounting and Economics, 21, 107-138. http://dx.doi.org/10.1016/0165-4101(95)00410-6

Lev, B., \& Zarowin, P. (1999). The boundaries of financial reporting and how to extend them. Journal of Accounting Research, 37, 353-385. http://dx.doi.org/10.2307/2491413

Matolsky, Z. P., \& Wyatt, A. (2008). The association between technological conditions and the market value of equity. The Accounting Review, 83, 479-518. http://dx.doi.org/10.2308/accr.2008.83.2.479

Mishkin, F. S. (1983). A rational expectation approach to macroeconomics. Chicago: University Chicago Presss.

Monahan, S. (2005). Conservatism, growth and the role of accounting numbers in the fundamental analysis process. Review of Accounting Studies, 10, 227-260. http://dx.doi.org/10.1007/s11142-005-1530-8

Nakamura, L. (2009). Intangible assets and national income accounting: Measuring a scientific revolution. Working Paper, Federal Reserve Bank of Philadelphia.

Pandit, S., Wasley, C. E., \& Zach, T. (2011). The effect of R\&D inputs and outputs on the relation between the uncertainty of future operating performance and R\&D expenditures. Journal of Accounting, Auditing, and Finance, 26(1), 121-144. http://dx.doi.org/10.1177/0148558X11400583

Petersen, M. A. (2009). Estimating standard errors in finance panel data sets: Comparing approaches. Review of Financial Studies, 22, 435-480. http://dx.doi.org/10.1093/rfs/hhn053

Sloan, R. G. (1996). Do stock prices fully reflect information in accruals and cash flows about future earnings?. Accounting Review, 71, 289-315.

Smith, J. V., \& Watts, R. L. (1992). The investment opportunity set and corporate financing, dividend, and compensation policies. Journal of Financial Economics, 32, 263-292. http://dx.doi.org/10.1016/0304-405X(92)90029-W

Sougiannis, T. (1994). The accounting based valuation of corporate R\&D. The Accounting Review, 69, 44-68.

\section{Notes}

Note 1 . The results are primarily same but slightly weaker when I use revision in long term growth estimate instead of percentage revision.

Note 2. The results are in the same direction when I use forecast errors in analysts long term growth estimate instead o percentage revision in analysts' forecasts. 